subjects, notably a paper (with Erichsen Jones) on the faunistic recovery of the Rheidol after leadpollution (Journal of Animal Ecology, 1938).

As a professor, Laurie was genial, imperturbable, persistent in the face of difficulties, and regarded with sincere affection by students and colleagues. $\mathrm{His}$ personal characteristics - he was like a cheerful robin -gave rise to a whole series of tales (true and legendary) which in time constituted a veritable collection of affectionate 'Lauriana'. His unflagging attempts to develop his department, including a phase during which he and his students built a lecture-room with their own hands, were prevented by fate and the Second World War from reaching full fruition by the time of his retirement.

It was not, however, Laurie's activities as a zoologist or as a professor which will be remembered. as his leading contribution to the welfare of his subject or his colleagues. The outstanding interest of his later years, and his chief service, lay in the field of organizations designed to promote the interests of university teachers and of university and educational affairs in general. It was Laurie's unfailing zeal, more than that of any other single person, which brought into existence the Association of University Teachers. He was its first president, in 1919, and was its honorary general secretary from 1920 to the time of his death. In addition (1943-53) he was honorary secretary-general to the International Association of University Professors and Lecturers, and it was at a conference of this organization that he died, after flying to Amsterdam, at the age of seventy-eight. Much of the credit for the achievements of these organizations may be traced back to Laurie's energy and enthusiasm. His educational interests were revealed in other ways, as in his reports for a British Association committee on the position of animal biology in the school curriculum; and he was responsible for the introduction of biological teaching in the grammar schools of Wales.

Laurie married Elinor Beatrice Ord in 1912, and both she and his daughter survive him. Mrs. Laurie has also for many ycars been beloved, not only by her family, but also in no common degree by her many friends, including those connected with her husband's enterprises.

T. A. STEPHENSON

\section{Dr. T. A. Jaggar}

DR. T. A. JAGGAR, dean of American volcanologists, died in Honolulu on January 17, just one week before his eighty-second birthday. Born in Philadelphia, Pennsylvania, on January 24, 1871, Thomas Augustus Jaggar, jun., was trained in public and private schools, and in 1893 received the degree of bachelor of arts in geology from Harvard University. He remained at Harvard to take his M.A. degree in 1894, and then spent most of the next two years studying at Munich and Heidelberg. Returning to Harvard, he was awarded the doctorate of philosophy in 1897.

During 1895-1903, Jaggar held an appointment as instructor in geology at Harvard, and in 1903 he was made an assistant professor. In 1906 he became professor and head of the Department of Geology at the Massachusetts Institute of Technology. During the summers he was a member of the United States Geological Survey, working in the Black Hills region of South Dakota and adjacent parts of Wyoming, in the Yellowstone National Park region, and in
Arizona. In 1901 he published, in the Annual Report of the Geological Survey, an important study of the laccoliths of the Black Hills.

Very early, Dr. Jaggar's interest turned to experimental geology, and the study of earth processes in the field. His visit to Martinique in 1902, to study the results of the catastrophic eruption of Mont Pelée, decided him to adopt as his life-work the fieldstudy of geophysics. From that time forward his major interest lay in the fields of seismology and volcanology, with a strong emphasis on the humanitarian aspects of both. His aim was the saving of human lives and property through the prediction of earthquakes and volcanic eruptions, the design of suitably resistant structures for countries subject to frequent earthquakes, and development of methods of protecting communities from the ravages of lava flows, glowing clouds, and heavy ash falls. Although he took part in many expeditions, Jaggar was firmly convinced that the only satisfactory way of studying volcanoes was by means of permanent observatories, keeping continuous records.

In 1912, Dr. Jaggar established the Hawaiian Volcano Observatory, for the continuous study, by direct physical methods, of Kilauea and Mauna Loa volcanoes. This was made possible by money provided from the Whitney Fund of the Massachusetts Institute of Technology, and funds subscribed by a group of business and political leaders of Hawaii that had formed the Hawaiian Volcano Research Association. For more than forty years the Hawaiian Observatory has carried on its work, under the Massachusetts Institute of Technology and later under successive agencies of the United States government. Dr. Jaggar remained its director until his retirement, in 1940 . He then became research associate in geophysies in the University of Hawaii, a position he still held at the time of his death.

Dr. Jaggar's contributions to the science of volcanology have been very great. Studies of the Kilauea lava lake demonstrated its complex nature, with a shallow pool of hot fluid lava lying on a semisolid but mobile plug. Measurements ascertained the distribution of temperature in the lake, and the composition of the liberated gases was determined. Tumescence and detumescence of the volcanic structure were demonstrated, probably resulting from changes in magmatic pressure beneath. The entire picture of volcanic activity was augmented and clarified. Perhaps most important of all, however, was the development by Jaggar and his associates of methods of aerial bombing to deflect lava flows, and the concept of huge diversion barriers to protect cities or harbours from inundation by lava. Jaggar never lost sight of the fact that the real purpose of science is to serve mankind.

$$
\text { Gordon A. Macdonald }
$$

WE regret to announce the following deaths :

Sir David Anderson, president during 1943-44 of the Institution of Civil Engineers, on March 27, aged soventy-two.

Dr. F. W. Edridge-Green, C.B.E., for many years special examiner and adviser to the Ministry of 'T'ransport on vision and colour vision, on April 17, aged eighty-nine.

Dr. G. F. Herbert Smith, C.B.E., formerly of the British Museum (Natural History), and honorary secretary since 1921 of the Society for the Promotion of Náture Reserves, on April 20, aged eighty. 